\title{
The Missing Tooth: \\ Case Illustrations of a Child's Assembled, Out-of-School Authorship
}

\author{
Kari-Lynn Winters \\ Brock University
}

\begin{abstract}
Case illustrations of a six-year-old boy's adventures with a missing tooth are used in this paper to re-define a broader notion of authorship. Drawing on theories of social semiotics, New Literacy Studies (NLS), and critical positioning, this notion of authorship not only interweaves the boy's preferred modes of meaning-making and communication, but also considers his sociocultural environments. Findings suggest that each mode of meaning-making (linguistic, symbolic, musical, etc.) has its own semiotic potential (both affordances and limitations) and that all authorship needs to be framed critically, within social contexts, in order to better understand and facilitate young children's abilities to garner, interpret, design, and communicate ideas across a range of semiotic systems.
\end{abstract}

Keywords: authorship, assemblage, multimodality, social practices, critical literacies

Kari-Lynn Winters is an award-winning scholar, children's author, playwright, and elementary school teacher. She is an assistant professor in the Faculty of Education at Brock University. Her interests include drama in education, children's literature, critical literacies, and multimodal forms of learning/communicating. More information about Kari-Lynn (including a detailed CV) can be found at: http://www.kariwinters.com.

Email: kwinters@brocku.ca

Brock Education, Vol. 22(1), Fall 2012, 3-25 


\section{Introduction}

Research suggests that children create and communicate by using a range of multimodal systems (e.g., drawing, singing, writing, talking) within their social contexts (Dyson, 1997; Jewitt \& Kress, 2003; Pahl \& Rowsell, 2005; Ranker, 2006). Additionally, within these environments they build critical power relations with others (Larson \& Marsh, 2005; Lewis, 2001; Marsh \& Millard, 2001; Moss, 2003). Defining authorship in these broader ways - in ways which include the multimodal, sociocultural, and the critical - have recently been publicly supported by international and national organizations (cf. Alliance for Excellent Education, 2012; IRA, 2011; NCTE, 2012). Yet despite research findings as well as concerted efforts from numerous organizations to expand notions of authorship, there is still a tendency to simplify it, to think of authorship as words alone or as an isolated, non-social event (Siegel, 2006; Winters, 2010). Instead of isolating authorship or opposing printed texts to other expressive forms (e.g., drawing, singing, writing), this paper suggests that authorship is always multimodal, social, and critical. Meaningful information is created and communicated through the processes of design, negotiation, production, and dissemination within diverse and differently situated communities. And within these social communities, authors identify power relations and develop their identities (Kendrick, 2003; 2005). When thinking of authorship in these broader ways, authors are offered broader and more authentic communicative options (Rogers, Winters, La Monde, \& Perry 2010; Stein, 2008; Winters \& Vratulis, in press.)

Using theories of social semiotics, New Literacy Studies, and critical positioning alongside close analyses of my son's out-of-school meaning making and communication, I demonstrate how even young children have the potential to author purposefully and with sophistication, in ways that are semiotic, social, and critical. Further, this paper offers a way to document and analyze these complexities, suggesting one way that education stakeholders (e.g., parents, administrators, teachers) might trace and assess broader notions of authorship (cf. Authorship as Assemblage, Winters, 2009). I believe that there is much at stake for education if adults continue to ignore children's representations of thought and their complex ways of knowing in an ever-changing global economy. Not only are we limiting children's thinking potentials by defining and practicing authorship in narrow ways, we are also disenfranchising children who have other pathways of sense making and communicating (Eisner, 1998; Pahl \& Rowsell, 2005; Walsh, 2011).

\section{Narrow Views of Authorship and Meaning-making}

People often think that authors only "write the words" and ignore the participatory and multimodal preparation as well as the sociocultural and critical understandings that they bring to their work (Dyson, 2004). As an author of 16 children's books, I encounter these narrow views of authorship all the time. Adults are frequently astonished when I explain that I take two years to write a picture book, or about the ways I generate ideas within social contexts, or the ways I play with different media in order to understand and write the story. Sometimes they respond with pitiful inflection, "Yes, it's easy to procrastinate" or "you should just put pen to paper and get on with it." Surprisingly, these people do not consider doodling an idea, charting actions, studying the craft of a scene from a movie or play, embodying a character, discussing themes, mapping plots, or any other "non-alphabet-based writing task" to be authorship. In other words, there is a perception that an author is only creating when printing letters, typing, or revising a manuscript (Dyson, 2004; Murray, 2004). Is this perception being brought into schools? Are young people only considered authors when they are physically writing with words? Do some modes carry more cachet (Dyson, 
2004; Jennifer Rowsell in conversation, June 2012)? Many authors believe and many researchers have shown (e.g., Kendrick, Rogers, Smythe, \& Anderson, 2005; Kress \& Van Leeuwen, 2001; Rogers et al., 2010; Sheridan \& Rowsell, 2010) that authorship happens all the time - throughout the day, every day, through a variety of modes (including the linguistic) — and always in relation to the social and cultural situational contexts these authors bring to bear.

This is not to say that speech and print are not important systems to master. Surely, without mastery of the linguistic mode, a child would not fully understand the potentials of authorship. As Heath (1983) and Janks (2010) have demonstrated, students who do not learn linguistic forms of writing have the potential to fall behind in school, may have additional problems in their communities, and may even encounter future difficulties in their adult years. Indeed, words are important, but as Graves (1999) writes, "[they] only represent one part of a thinker's inner language" (p. 79). Thus, by privileging the linguistic mode and by not attending to the multiple systems of representation and communication students bring to bear, education stakeholders may be depriving students of reaching their fullest thinking potentials.

\section{Modally Integrated, Participatory, and Critical Visions for Authorship}

Becoming literate, in the broadest sense means learning how to access in a meaningful way the forms of life that meaning systems make possible. (Eisner, 1998, p. 12)

Longstanding evidence from education scholars and literacy researchers (e.g. Dyson, 1997; 2004; Harste, Woodward, \& Burke, 1984; Harste, Short, \& Burke, 1996; Kress, 1993; 1997; Siegel, 1995; Street, 1984), plus the significant contribution of education critic Elliot Eisner (1998), demonstrate that meaning making is always a participatory and modally-integrated process. In regard to writing, others too have demonstrated for nearly twenty years that authorship does not begin when an author picks up a pencil or types on a computer (Bakhtin, 1986; Calkins, 1994; Graves, 1999; Kress, 1997), nor does it only occur in schools or the workplace (Barton \& Ivanic, 1991; Kress, 1997; Murray, 2004). Rather, authorship is constantly being composed and communicated by authors across multiple modes and social environments. Within these modal and social spaces, power is always being negotiated. The concept of authorship, like any other "ideological" practice, always links semiotic resources and individual agency within social structures (Janks; 2010; Winters \& Vratulis, in press). In this paper, authorship is defined as the assembled semiotic, social, and critical process of designing, negotiating, producing, and disseminating meaningful information within diverse and differently situated communities. Moreover, an author is defined as any person or group who "donates meaning" (Barthes, 1977) within situational contexts to any piece of work, be it declared, hidden, or withdrawn (Winters, 2009). This broader definition of what it means to be an author not only suggests that meaning-making and communication are more expansive than language alone, but that within contexts authors compose and communicate both internally (designing and negotiating) and externally (producing and disseminating), adding to the social texts or cultural storylines that are being created. Defined in this broader way, it is important to note that authorship includes both the interpretation and the actualization of information.

Declared authors are those that are visibly present; they can be seen or heard creating meaning and contributing to a text within a social context (Barthes, 1977). For example, through case illustrations shown later in the article, a child, Leon, can be seen creating a map. Hidden or withdrawn participants in this paper include authors that are less visible or may have "dialogically" at one time been involved in donating meaning (Bakhtin, 1981; Barthes, 1977), such as Leon's 
classmates, who called him a "baby" in the weeks before his first tooth fell out. These hidden participants play a role in this literacy event, for these authors positioned Leon in particular ways and within the narratives he creates (Davies \& Harré, 1990; Holland, Lachicotte, Skinner, \& Cain, 1998). Looking at authorship through this extended lens not only offers nuanced and layered perspectives, it suggests that authorship is always modally constructed and socially- and criticallynegotiated. And it poses broader questions about the participatory nature of communication, modal integration, recursive meaning making, and the ways children situate themselves within contexts and construct power relations (Holland, et al., 1998; Janks, 2010).

\section{Background Theories of Modal Authorship}

At its most fundamental level, semiotics — from the Greek work semion ( $\sigma \eta \mu \varepsilon 10 n)$, "sign" — is the study of symbols or signs. This field was founded on two divergent traditions: the work of the Swiss linguist Ferdinand Saussure (1916), and the Peircian tradition, from American philosopher Charles Sanders Peirce (1931).

While Peirce's tradition of semiotics does suggest a combination of the social and the semiotic, the social is often implicit. Scholars such as Vygotsky (1980), Hodge and Kress (1988), and Van Leeuwen (2005) have critiqued Peirce's model, arguing that semiotics should not be and can not be devoid of the socio-cultural contexts in which they are embedded, because meaningmaking and communication never occur in isolation. These more recent theories extend the field of New Literacy Studies, a field that emphasizes that semiotic resources are not composed in silos, but rather, within various and situated communities of social practice (Kress, 2010; Pahl \& Rowsell, 2005; Larson \& Marsh, 2005; Rogers \& Winters, 2010).

What is important about contemporary notions of multimodal authorship and to this paper is how knowledge is always simultaneously constituted and communicated on multiple levels: (1) through specific semiotic modes and resources; (2) by individual or groups who come with their own values, beliefs, and so forth; and (3) within social practices and situated contexts. Authors help to shape the communicational situations they encounter, co-constituting the social and modal interactions that are assembled (Janks, 2010; Kress, 2010; Rogers et al., 2010).

A recent study exemplifies these ideas about multimodality, specifically one that investigates children's use of iPads in a grade three classroom (Rowsell \& Walsh, 2011). These scholars suggest that today's authorship is both semiotically integrative and socially interactive. They demonstrate that with the development of "Web 2.0," technology literacy has changed and expanded, making it neither sensible nor feasible to continue to separate the linguistic processes of reading or writing from the modes that are semiotically integrated, nor from the authors themselves and the social relations that they bring into these processes. In other words, multimodality (including digital technologies and other modes of meaning-making) has permeated the ways that people design, negotiate, produce, and disseminate information. Therefore, without a push to redefine multimodal authorship in social, semiotic, and critical ways, "educators run the risk of teaching and learning language and literacy skills in anachronistic paradigms and frameworks" (Rowsell \& Walsh, 2011, p. 53).

\section{Social Out-of-School Literacy Practices}

New Literacy Studies (NLS) are theoretically grounded in the fields of social semiotics, sociocultural theories and ethnographies, digital technologies, and the shifting landscape of literacy. 
Scholars from this field have not only demonstrated that what counts as text and what constitutes reading and writing are changing - but rather, that they have already changed (Hull \& Nelson, 2005; Kress, 2010; Kress \& Van Leeuwen, 2001; New London Group, 2000). Indeed, broader literacy frameworks compiled with a proliferation of accessible modalities demand that schools reinterpret what is required for students to emerge as literate citizens (Jewitt \& Kress, 2003; Lankshear \& Knobel, 2003; Pahl \& Rowsell, 2005; Stein, 2008). When using technology, for example, semiotic resources are not seen in opposition to one another; when used together, they can advance students' meaningful constructions of knowledge and communicative options (Larson \& Marsh, 2005; Walsh, 2011).

Scholars also demonstrate that children naturally move between semiotic systems in their outof-school environments (Kendrick, 2003; 2005; Kendrick et al., 2005; Ranker, 2006; Pahl, 2003). Perhaps this is because they are less inhibited by the school's structured routines and rules of engagement (e.g., including notions of common practice, affordances of eligibility/authority, distributions of power), or perhaps because they intuitively recognize that no one semiotic system fully represents all the possible knowledge available on any one topic. Regardless, when children are given authentic opportunities to render meaning across multiple semiotic systems, they have broader opportunities to take control of their own learning and to generate new and diverse organizations of meaning (Ranker, 2006; Rogers \& Winters, 2010; Winters \& Vratulis, in press). However, new literacy researchers Larson and Marsh (2005) posit that there is still a void in the literature that closely analyzes children's out-of-school thinking and communicative practices. They urge other scholars and education stakeholders (e.g., parents, administrators, teachers, researchers) to also consider children's out-of-school communicative practices - which involve a wide array of modes - because the home is not only intimately connected to the meanings children produce, but it also shapes their in-school communication.

\section{Critical Positioning}

While combining the social and the semiotic is becoming a more trodden ground in the field of literacy education, criticality is often an implicit factor (Stein, 2008, Kress, 2010). For example, multimodality scholar Gunther Kress (2010) writes:

Authorship, in particular, is in urgent need of theorizing.... the redistribution of power in communication, an effect jointly of the social conditions.... and the facilities of digital devices, both leading to the remaking of power-relations, has the most profound effect on conceptions of learning of knowledge and hence on the formation of subjectivity and identity. (p. 21)

Kress goes on to say that young people negotiate and act within their own notions of identity and power and that authority can not be separated from authorship, nor from the spaces where literacy is constructed and communicated. This idea resonates with the work of Pippa Stein (2008), Hillary Janks (2010), and Rogers and Winters (2010). These literacy scholars suggest that situational power relations need to be captured in studies, including ideas around participant subjectivities, contexts, access and eligibility, and structured routines, in order to better understand the various ways that young people narrate their social identities, participate in the world, and ultimately shape global literacy practices. 
Davies and Harré (1990) coined a theory called "Discursive Positioning," which highlights the ways that, within discourses, authors imagine storylines for themselves and others. They suggest that authors shape their situational contexts by assuming and assigning flexible and imagined positions in order to psychologically or physically locate themselves. Some scholars (Holland et al., 1998; Holland \& Leander, 2004; Winters \& Vratulis, in press) discuss how these discursive positions play out in varied social situations, further demonstrating how people create storylines in order to know their own lives, and further, to author how their lives connect to the lives of others. Discursive positioning theories are taken into consideration in this paper to better understand the place of power and empowerment within children's authorship practices.

\section{Method and Study Context}

During the summer of 2006 I had the opportunity to observe and collect data on my son Leon ${ }^{*}$ for three weeks across several of his out-of-school contexts. I used a side-shadowing interview technique (McClay \& Mackey, 2009), where I sat next to Leon keeping detailed research notes (both in the moment and reflective), interviewing him, collecting documents/artifacts that he created, and audio/video-taping whenever possible. In this way, Leon's meaning making and communications guided the study.

Leon, then six-years-old (in kindergarten), is a sensitive and thoughtful Caucasian boy who loves Lego, computer games, reading books, and writing in his journal. At the time of the study, Leon had just became a big brother to Kenzie and the caretaker of his two cats. I was finishing grad school and Leon's father, John, was finishing a training program to become a registered massage therapist. Together our income totaled just over $\$ 23,000$, well below the poverty line. The six of us (Leon, myself, his father, sister, and two cats) lived in an urban environment in Western Canada in a one-bedroom apartment. Being scholars, John and I were both very involved with Leon's education and schooling continues to be a high priority. Leon's teacher often told John at pick-up time about Leon's day and made comments such as "Leon is the top of his class in academics" or "he is a leader on the playground." Leon's report cards support these claims, stating that in class he is studious and attentive. Leon has many friends at school, with whom he loves to talk and play, but he is also quite content to play on his own. Many of these friends have developed faster (physically) than Leon and have lost their teeth. This was an important aspect of Leon's school culture at the time the data were collected.

I was curious about the ways that Leon constructed and shared meaning, particularly his thinking and communication processes within his out-of-school environments. For these three weeks, I was with Leon as much as possible, recording throughout the day, every day. In total, I captured/transcribed over 168 hours of data. When it was time to code and analyze the data, I first looked for narrative themes. Several themes emerged, including sports and activities, relationships with others, boys vs. girls, etc. One special theme, indicative of Leon's age and development, was about losing baby teeth. I compiled these data in the form of narrative case illustrations. Then, using the "Authorship as Assemblage" framework shown below (see Table 1 in the following section), I began analyzing, with specific regard of the semiotic, the social, and the critical theories mentioned above.

\footnotetext{
*All names (son, daughter, husband, and Leon's friend Atlan) have been changed.
} 


\section{An Analytic Framework - Authorship as Assemblage}

Drawing upon the semiotic, the social, and the critical together, I devised an analytic frame called Authorship as Assemblage (cf. Winters, 2009; 2010). This theoretical and analytic framework emphasizes modal choices, situated contexts, and critical storylines. Here, theories speak back to one another and to the data, suggesting that meaning making and communication are always fluid, interconnected, and recursive. Additionally this framework suggests ways that multimodality can be coded and transcribed.

In the next section I apply this framework to case illustrations of a six-year-old boy in order to better understand and document the different ways this child authors in his out-of school environments. I am particularly interested in knowing:

- how this young child becomes both a consumer and a producer of modal texts;

- which semiotic resources Leon chooses, along with the potentials of these resources;

- what social "inter(actions)" (Winters, 2009) shape and are shaped by Leon; and

- how Leon discursively positions himself as he authors (Baldry \& Thibault, 2006).

Table 1. Authorship as Assemblage Framework

\begin{tabular}{|c|c|c|c|c|c|c|}
\hline $\begin{array}{c}\text { Discursive } \\
\text { Event }\end{array}$ & $\begin{array}{c}\text { Principle \#1 } \\
\text { External and } \\
\text { Internal } \\
\text { Meaning- } \\
\text { Making }\end{array}$ & \multicolumn{2}{|c|}{$\begin{array}{c}\text { Principle \#2 } \\
\text { Semiotic Resources }\end{array}$} & $\begin{array}{c}\text { Principle \#3 } \\
\text { Social } \\
\text { (Inter)actions }\end{array}$ & \multicolumn{2}{|c|}{$\begin{array}{c}\text { Principle \#4 } \\
\text { Discursive Positions of Author }\end{array}$} \\
\hline & $\begin{array}{c}\text { Declared, } \\
\text { Hidden, or } \\
\text { Withdrawn }\end{array}$ & $\begin{array}{c}\text { Semiotic } \\
\text { Resources }\end{array}$ & $\begin{array}{c}\text { Semiotic } \\
\text { Potential }\end{array}$ & $\begin{array}{c}\text { Designs } \\
\text { Negotiations } \\
\text { Productions } \\
\text { Disseminations }\end{array}$ & $\begin{array}{c}\text { Of self } \\
\text { Of others }\end{array}$ & $\begin{array}{c}\text { Structured Routines e.g., } \\
\text { Who is eligible, rules of } \\
\text { engagement }\end{array}$ \\
\hline
\end{tabular}

This analytic frame draws from the work of Barthes (1977), Bakhtin (1981), Kress and Van Leeuwen (2001), Baldry and Thibault (2006), Davies and Harré (1990), and to some extent the work of Hamilton (2000). Each element of the frame is defined in Appendix A.

\section{Narrative Case Illustrations}

In this section, I use two different fonts in order to distinguish the "field notes or transcriptions collected at the time" (rendered in italics) from the "data analyses" interpreted after data were collected (rendered in non-italic Roman).

Case Illustration $1-$ July $15^{\text {th }}, 2006$

It is a summer day in Western Vancouver, Canada. Leon is eating an apple, which he believes will make his loose tooth fall out. Over the past week, Leon has expressed an interest in teeth. Not only is his loose tooth a common topic of conversation, he can be seen wiggling it regularly.

When finished eating, he decides to read a book entitled Franklin and the Tooth Fairy (written by Paulette Bourgeois and illustrated by Brenda Clark). It is a story about a little turtle named 
Franklin who doesn't have any teeth. Franklin believes he will never "grow up" or get a reward from the tooth fairy. So he tricks the tooth fairy by putting a tooth-shaped white rock under his turtle shell. The tooth fairy, however, cannot be outsmarted. In the end, Franklin's parents give him a present to celebrate his growing up.

Leon (laughing and pointing at the pictures): The tooth fairy would never fall for that joke.

Me: Why not?

Leon: Because the tooth fairy is smart and magical. And besides, loosing a tooth is serious business.

Me: How?

Leon: Kids really do make fun of you if you don't lose a tooth. Sometimes they call you (emphasizing the word) "BABY!"

According to Leon's teacher, Leon had an encounter at school the week prior. Apparently the children in Leon's grade class, those who have lost teeth, called him "baby".

Critical positioning theorists (Davies and Harré, 1990; Holland et al., 1998) suggest that authors position themselves in terms of categories (e.g. I have lost a tooth vs. I have not lost a tooth) and imagined storylines (e.g., Franklin and I are both worried we will never grow up this is "serious business") based on their own experiences. Once located within these discursive spaces, children learn about themselves, their relationships with others, and about power differentials. Here, the affordances of a fictional storybook seem to give Leon a better understanding of himself and his previous school playground encounter.

This conversation reminds me of a set of pictures I had just been emailed.

Me: Leon, come and see these pictures.

Leon runs over to the computer. The caption for the digital photograph reads "And Then There Were None." The photograph shows Leon's friend smiling a gummy toothless grin. He had apparently lost his four front teeth in the previous week. Leon laughs again, and then tries to wiggle his own loose tooth.

Leon (dancing): Look! Mine's gonna fall out soon too!

He pushes at the tooth forward, twisting it awkwardly in his mouth.

In this case illustration, Leon's authorship is primarily linguistic and gestured. Leon chooses the linguistic mode to articulate specific memories (e.g., "Sometimes they call you BABY!") and his subjectivities (e.g., "...the tooth fairy is smart and magical”). Meanwhile, the gestures he uses afford spatial and emotional potentials (e.g., demonstrating which tooth is loose, dancing his excitement). Together, the modes and his previous social relationships interanimate each other (Winters \& Vratulis, in press), resulting in a totality of meaning that is greater than the sum of its parts. His actions and words together clarify and expand his communication.

Case Illustration $2-$ July $16^{\text {th }}, 2006$

The next day, Leon and I go to Jericho Beach to meet friends and play. Leon and a friend have a water fight. During their play, Leon, in order to avoid a solid soaking, trips and loses his balance. He quickly moves his knee forward to stabilize himself but ends up hitting his mouth on his knee. At once, blood drips downward and is absorbed into the sand. At first Leon looks panicked, then notices his tooth is missing. He smiles and points to his blood-soaked mouth, gesturing the 
message that he lost his first tooth. My friend Sandy and I grab towels, trying to help him. At a loss for words, Leon continues to point out his good news. Then, suddenly it dawns on him: he needs to retrieve his tooth so that he will receive a reward from the Tooth Fairy. His smile turns into a look of fear. He falls to his knees and frantically sifts through the sand.

Leon: If I don't find it the tooth fairy won't come!

Sandy, Sandy's son (Leon's friend), and I try to help him, but it is no use - there are thousands of tooth-shaped white rocks.

On the walk back to the car, I see Leon pick up a small white rock.

Me: Whatcha doing?

Leon (muttering): Just in case.

We stop at Sandy's house to clean up the blood and change our clothes. From his body language (looking around, tapping his foot, pursing his lips), it appears as though Leon is becoming more and more anxious.

Leon (blurting out): The tooth fairy will never come now!

Me: Yes she will.

Leon: How can she? She won't know where to come.

Me: She'll know. She's magic, remember?

Apparently my reassurance is not enough. Leon asks for a pencil and a piece of paper. He draws a map, complete with a compass rose, indicating North, South, East and West (see Figure 1). The map includes the places that are important to Leon, including his own house in what he calls "the city", Sandy's house, and (most important) an X to mark the spot on Jericho Beach. He also indicates with parallel lines the route that the tooth fairy should take. Creating this map calms Leon.

Leon: At least now she will know where to go to find my tooth.

Do children know intuitively about the semiotic potential of different systems? From reviewing this case illustration, it appeared that Leon did. For he moved between different semiotic systems, choosing the ones that would most aptly provide the kinds of meaning he desired. For example, when Leon wanted the tooth fairy to know where he lost his tooth, he drew a map (Figure 1). He knew that maps afford spatial information. But so do pictures. Why then did Leon choose to draw a map rather than a picture? This is where the "functionality" of each mode of representation becomes important (Halliday, 1975; 2004). I believe that Leon may have chosen to draw a map rather than a picture for two reasons. First he needed to convey to the Tooth Fairy the exact location of the tooth. He didn't want to show a picture of any beach (what a drawing of a beach might afford), he needed to show a specific beach, Jericho Beach. Because maps combine both pictorial and linguistic semiotic resources into one layered or hybrid system, Leon could convey to his audience (the Tooth Fairy) the exact location of his tooth. Second, he drew a map to demonstrate a spatial relationship, where his home was in relation to Jericho Beach. His map affords a specific route that the Tooth Fairy can take. And if the Tooth Fairy can't find the tooth, Leon himself has a resource that will guide him in order to find it.

The map itself affects Leon's critical identity construction. It gives him an opportunity to reposition himself, taking him from a place of helplessness (i.e. a boy who lost his tooth) to a place of empowerment (i.e. a boy who has the tool that will help the Tooth Fairy locate his tooth). 


\section{Figure 1. Leon's Map}

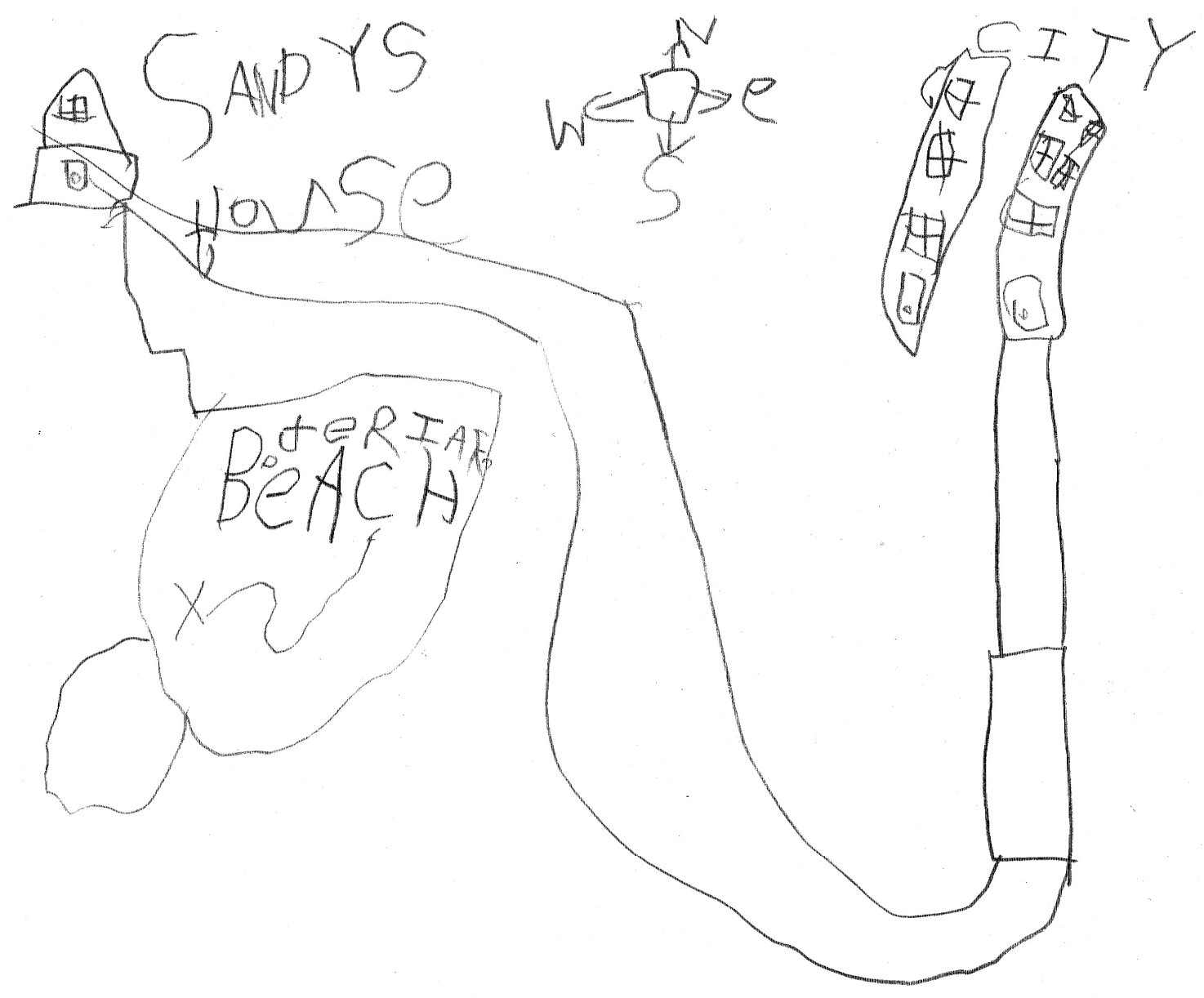

$\underline{\text { Case Illustration } 3-\text { July } 16^{\text {th }}, 2006}$

That evening, Leon's thoughts go back to the tooth fairy.

Leon: Do you think she'll come?

He fidgets with his pajama buttons, appearing upset that he has no way to communicate with her.

Me: She'll come.

Leon frowns, demonstrating his disbelief. Unsatisfied, Leon composes a letter (see Figure 2): 
Figure 2. Leon's Letter to the Tooth Fairy

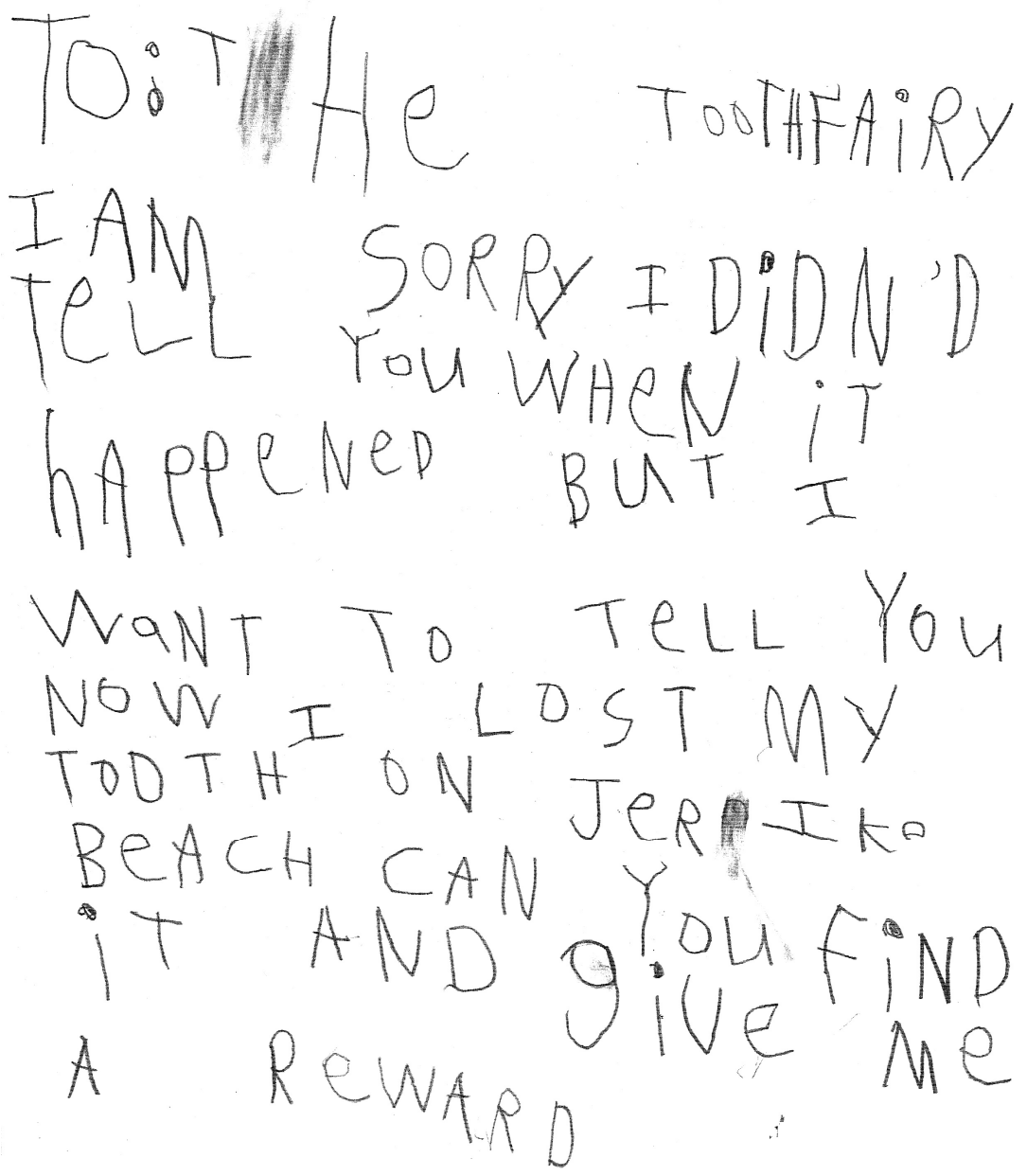

(To: The TooTHFAiRY I AM SORRY I DIDN'D TELL YOU WHEN IT HAPPeNeD BUT I WANT TO TELL YOU NOW I LOST MY TOOTH ON JERRIKO BEACH CAN YOU FIND It AND give Me A ReWARD)

He carefully folds the map and the letter and puts them both under his pillow.

Typically, children in North America put their tooth under their pillow in order to claim a reward from the tooth fairy. Leon knew this tradition, not from personal experience - as this was his first tooth to fall out - but from literature and the media (e.g. books he has read, television shows he has watched). Yet, it occurred to Leon that the tooth fairy might not show up because he didn't have a tooth to put under his pillow. "Do you think she'll come?" he asked. To ensure her arrival, he wrote a letter.

Why did Leon write a letter instead of, perhaps, singing a song, acting out a play, or drawing a picture? NLS research suggests that authors use particular resources and materials in specific situational contexts because each elucidates its own particular "semiotic potential," its own affordances and limitations (Jewitt \& Kress, 2003; Baldry \& Thibault, 2006; Van Leeuwen, 2005). I believe that Leon chose to write a letter for a couple reasons. First, writing affords evidence of its occurrence. There is a permanence about the written text (Halliday, 2007; Kress, 1997). Because the 
tooth fairy was not there yet, he was unable to simply have a spoken conversation with her. Yet, a drawing of the event would have also offered concrete evidence; why didn't Leon create a picture? Perhaps because a drawing can be "polysemous" (Baldry \& Thibault, 2006) or too open for interpretation, and it may not have offered the specific meaning he needed to communicate. Here, he needed to address the tooth fairy, not an elf fairy or a flower fairy and so forth. Second, Leon is familiar with the genre of letter writing. He has written and received letters at school and he had recently just read the story Franklin and the Tooth Fairy, where he saw that the Tooth Fairy reads children's (and turtles') letters. Moreover, writing a letter is something he is able to do. If perhaps he didn't know the alphabetic code, he may have chosen another more accessible semiotic system (e.g. pictorial) or a different mode of production (e.g. transcribing his letter to Kate) (Walsh, 2011). In this instance, he could position himself as an "able writer."

Writing a letter gave Leon these distinct affordances: (1) the ability to address a specific reader, the Tooth Fairy; (2) to communicate his emotional thoughts; (3) to recount his story; (4) to persuade his reader; and (5) to orient his reader. Table 2 demonstrates the close analysis that I made of Leon's letter, specifically recognizing the semiotic, social, and critical potentials that he identified with.

Table 2. Semiotic, Social, and Critical Potentials of Leon's Letter to the Tooth Fairy

\begin{tabular}{|l|l|}
\hline Evidence of a Written Letter Text & \multicolumn{1}{|c|}{ Potentials of a Written Letter Text } \\
\hline To: The TooTH FAiRY & $\begin{array}{l}\text { 1) To address his reader: } \\
\text { Leon addresses a specific reader - the tooth } \\
\text { fairy, demonstrating his cultural beliefs and } \\
\text { situated context. }\end{array}$ \\
\hline $\begin{array}{l}\text { I AM SORRY I DIDN'D } \\
\text { TELL YOU WHEN IT } \\
\text { WAPPeNeD BUT I }\end{array}$ & $\begin{array}{l}\text { 2) To communicate emotions and thoughts: } \\
\text { Leon explains that he forgot to tell (perhaps by } \\
\text { writing a letter) the tooth fairy about losing his } \\
\text { NOoth earlier in the day and that he has a } \\
\text { purpose for telling (writing the letter) now. }\end{array}$ \\
\hline $\begin{array}{l}\text { I LOST MY TOOTH } \\
\text { ON JeRRIKO }\end{array}$ & $\begin{array}{l}\text { 3) To recount his story: } \\
\text { Be tells the tooth fairy where he lost his tooth. } \\
\text { At the same time, he is given an opportunity to } \\
\text { set up his circumstances. }\end{array}$ \\
\hline $\begin{array}{l}\text { CAN YOU FIND } \\
\text { A ReW give Me }\end{array}$ & $\begin{array}{l}\text { 4) To persuade his reader: } \\
\text { He asks the tooth fairy to help him find the } \\
\text { tooth and to give him a reward. He positions } \\
\text { himself as someone who needs help and as } \\
\text { someone who is deserving of a reward. }\end{array}$ \\
\hline FROM: & $\begin{array}{l}\text { 5) Orient his reader: } \\
\text { So the tooth fairy knows who to give the } \\
\text { reward to, Leon offers information about who } \\
\text { wrote the letter. }\end{array}$ \\
\hline
\end{tabular}


Case Illustration $4-$ July $17^{\text {th }}, 2006$

The next morning, Leon discovered the envelope with his name on it. Inside he found $\$ 5.00$ along with a letter. Leon hummed a gleeful song as he flashed the money and danced around the room (see Figure 3).

Figure 3: Leon's Song
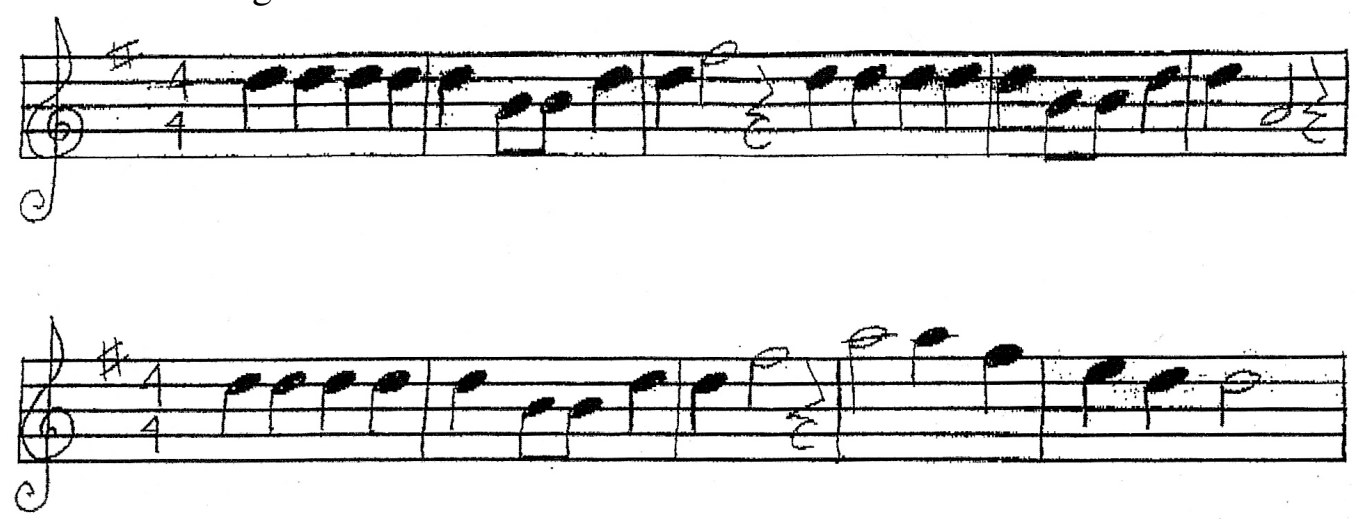

(transcribed from an audio recording by a professional musician)

Me: What does the letter say?

Leon reads the letter (see Figure 4).

\section{Figure 4: Letter From the Tooth Fairy}

\section{Dear Leon,}

I found your tooth at Jericho Beach.

Thank you for the map and for the letter too.

Here is your reward.

Love: The tooth Fairy

P.s. I like teeth like yours - the ones without cavities. So keep brushing and flossing.

Me: That's a lot of money!

Leon: Well, which would you want? A rotten apple or a good, healthy, tasty apple?

Me: The good one.

Leon: Well the same is true with the tooth fairy. I got $\$ 5.00$ because I kept my tooth clean and healthy.

Me: That must be why.

The song Leon hummed authentically demonstrated his happy mood. Music has the potential to create some meanings that challenge and elude linguistic semiotic systems. For example, music has the potential to carry visceral knowledge (such as emotional messages) that is felt in deeply intuitive and embodied ways (Van Leeuwen, 1999). 
In this social context, Leon positions himself as the informant. He suspects that his mother will want to know what reward the tooth fairy gave him. Leon, wanting to convey his enthusiasm, goes beyond simply telling the story; he sings and dances it. Here, the song, the gestures, the dance, and the socio-critical meanings behind the letter interanimate one another, providing a joyful environment.

Some scholars argue that music, like pictorial systems, can also be "polysemous," too open for definite interpretation (Barthes, 1977). This is because musical notation systems seem more arbitrary (there is no apparent reason why certain musical notes signify certain moods) (Baldry \& Thibault, 2006; Van Leeuwen, 1999). Moreover, without lyrics it may be difficult to interpret an author's exact meaning. So without the assemblage he constructed - the social context, the semiotic resources employed together (the artifact in his hand, the song, the gestures), and the ways Leon positioned himself, I might not have understood the meaning he was composing and communicating. For instance, if I had home from work and found Leon singing a gleeful tune, I might believe that Leon simply had a good day at school. However, by assembling the semiotic, the social, and the critical together, I was given a chance to better understand the ways that Leon thinks, communicates, and is shaped by his literacy practices. Additionally, by assembling these three systems together (the semiotic, the social, and the critical), Leon was given more opportunities to express and reshape meaning and to position himself as an expert meaning-maker.

It is important to note that, although a song without lyrics may be considered arbitrary, it is never culturally neutral. Leon and I live in a society where songs that hold quick, constant rhythms and upbeat melodies have the potential to evoke happiness (e.g., "Happy Birthday" or "For He's A Jolly Good Fellow"). As NLS researchers have suggested, semiotic systems impart the potential to frame our experience because we cannot escape the social, historical, and cultural worlds that we inhabit (Janks, 2010; Kress, 2010; Rogers \& Winters, 2010).

\section{Case Illustration $5-$ July $18^{\text {th }}, 2006$}

Later, Leon realizes that his grandparents might like to know about his missing tooth too. He asks if he can call them.

Me: Both Nana and Bubba are at work. You will have to wait until they get home.

But Leon can't wait. Instead he pulls out a piece of paper and tries to draw a picture of how he lost his tooth. His picture appears cluttered and filled with random pictures and words (e.g. Leon with his toothless grin, a beach-like scene, red marks "to show blood," he explains); a map similar to the one he drew earlier; a little elf-like girl with wings; and a $\$ 5.00$ bill. Leon huffs with frustration. His eyes well with tears.

Me: What's wrong?

Leon: I don't like it. I don't have enough space. How can I remember everything to tell when I don't have enough space?"

Me: It looks fine. I can see the whole story.

Leon: That's because you were there. Anyways, I don't like it!

And with that comment, Leon rips up the paper and puts it in the trash. I stare at him, confused.

Me: Now what are you going to do?"

Leon: Draw another one. A better one.

Leon sits down again. He picks up a pencil and draws lines, charting out his paper into eight sections. He draws a comic strip (see Figure 5). 


\section{Figure 5. Leon's Comic Strip}

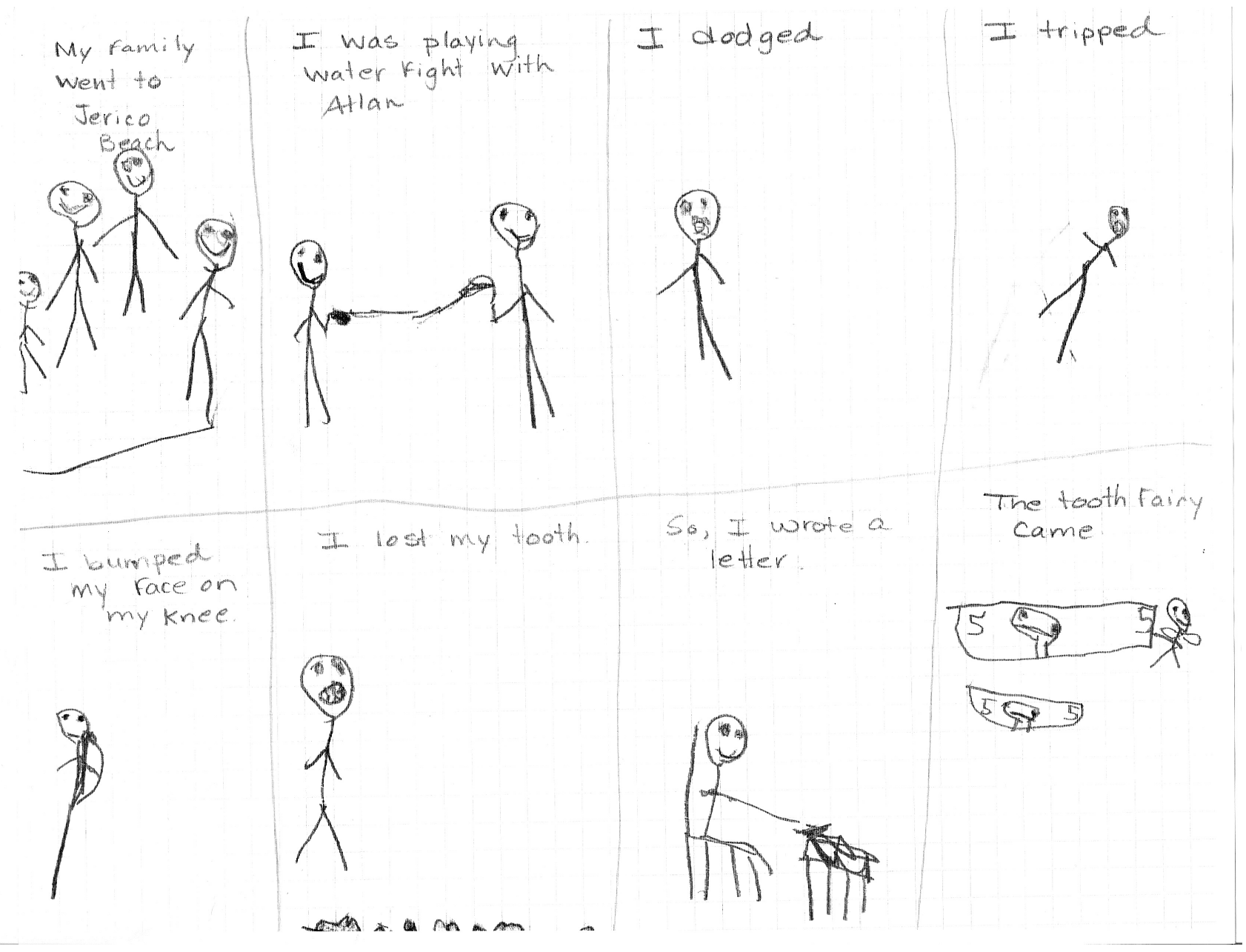

Next, Leon draws the stick figures.

Leon: Can you write the words small enough?

Me: To fit in the frames? Yes, I can help.

He recites, pointing to the different frames:

My family went to Jericho Beach.

I was playing water fight with Atlan.

I dodged.

I tripped.

I bumped my face on my knee.

Brock Education, Vol. 22(1), 3-25 
I lost my tooth.

So, I wrote a letter.

The tooth fairy came.

Feeling satisfied, he places his comic strip beside the phone.

\section{Leon: This will remind me what to tell Nana and Bubba.}

Here, more than the other case illustrations, I realized that I was a part of Leon's critical world and that my intentions were also playing a role in our situational context. For example, I really didn't want him to rip up the picture he had drawn, because I wanted to keep it as data. Although Leon probably didn't recognize it at the time (he certainly didn't let on that he did), he assumed a position of power by ripping the paper. By destroying something I wanted, not only did he become empowered, his reaction disempowered me.

Leon decided to create a comic strip rather than a picture. Comics, like maps, interweave linguistic and pictorial semiotic resources. Assembling these two systems together has its advantages. As Eisner (1998) argues, linguistic systems alone are limiting because they tend to "homogenize," or treat members or objects as a particular class. For example, when we say "that is an oak tree," we are suggesting that all oak trees are the same. Pictures, on the other hand, show the distinctness of each particular tree. Additionally, using only linguistic semiotic systems makes it tricky to demonstrate the social distances between people and objects or certain gestured movements (e.g. gaze). Yet pictures, in isolation, have limitations too. For example, because pictorial semiotic systems are organized spatially, not temporally, it is difficult to demonstrate time. Graphic devices such as a clock or the location of the sun, or a sequence of pictures, are sometimes used to convey these temporal factors.

Given that comics recognize the affordances of at least two different semiotic systems, Leon could author more nuanced meanings than he could express with either the picture or the words alone. Thus not only did the comic format offer Leon a new design choice - one that enabled him to assemble multiple semiotic resources together - it positioned him as a legitimate storyteller and gave him a pathway to remember the event.

Individual authors have distinct ways of symbolizing their memories and knowledge; these ways do not always "fit" with institutional expectations for literacy practices (Kendrick, 2005). I wonder how, if Leon were in school, he might negotiate this situation? Would the structures and routines of school allow him to rip up his picture in order to design a comic? And if this weren't the case, what happens to children like Leon - children who rely on multimodal design choices in order to tell/show their stories, to shape their identities, and to participate in their social and cultural worlds? Anne Dyson (1997; 2001) discusses this idea. She argues that writing programs need to shift their emphasis away from writing mechanics to broader emphases on communication, including all the modes it encompasses. All authorship exists in and relies upon other people's contexts (e.g., at schools). As children interact with their social worlds (e.g., through authored designs, negotiations, productions, and disseminations), they call upon and use the semiotic resources available to them, while at the same time positioning themselves within the structured routines and common practices of these environments. Therefore, the author is always internalizing and externalizing his/her own identity and at the same time shaping and participating in larger cultural dialogues. (Holland et al., 1998; Rogers et al., 2010). This means that social and modal 
utterances lean on each other in complicated ways and that critical relations of power play a role in shaping individual and group identities.

\section{Discussion}

For nearly a week (of the three weeks when data were collected), Leon authored an assemblage of what it might meant to lose a tooth, demonstrating what Eco (1978) and Halliday (1975) suggested decades ago: there are multiple pathways to any one piece of knowledge. Leon fluidly wove webs of meanings using the semiotic systems that were available to him within his social contexts. And at the same time, within each situation he created imagined storylines, assuming and assigning subject positions. This case illustration suggests that even young children have the ability to weave together diverse semiotic, social, and critical systems in rich ways.

Eisner (1998) states that each mode "enables us to experience the world in ways that are distinctive" (p. 15). This is because each semiotic resource holds its own meaning potentials and limitations (Baldry \& Thibault, 2006; Eisner, 1998; Halliday, 1975; Kress \&Van Leeuwen, 2001) and its own processes of meaning making/communication. For example,

Musical cognition requires the individual to think about, experiment with, and control patterned sound. The ability to write poetically requires skill in the creation of allusion and an ear for the melody of language. Visual art makes demands upon the student's ability to perceive emerging opportunities on the canvas, paper, or clay and to control materials well enough to mediate the possibilities he or she conceives. (Eisner, 1998, p. 17)

When assembled together, semiotic resources, social environments, and power relations have the potential to interanimate one another, whereby meaning becomes layered and re-mixed (Winters \& Vratulis, in press). Moreover, when authors are given opportunities to authentically assemble and embed these hybridized meanings into their daily lives — as children do at home - they are given additional opportunities to think through and negotiate their social and critical surroundings.

In addition, authors position themselves and are positioned by the literacies that are embedded in their lives. This positioning is based on the contexts that surround them, including their preferred authorship practices, the materials that are available to them, the audience they are addressing, their personal histories and experiences, distributions of power, etc. (Davies \& Harré, 1990; Janks, 2010). The case illustrations demonstrate that, through multiple semiotic resources, Leon sees himself as someone who has the power to offer directions, to persuade, to express his emotions, and to retell/reshow his own story.

Leon's relationships with others and the modes he was using were taken up and re-mixed across social contexts in fluid, recursive ways - in ways that I would argue were "assembled" (Winters, 2009). For instance, Leon used a musical semiotic system (singing a tune) in order to convey his enthusiastic mood. However, this was not the only semiotic resource functioning at the time, for he also used the semiotic resource of gesture (gross motor movements and facial expressions) and the visual semiotic resource (the artifact or the bill itself) to indicate his pleasure. This example demonstrates what some researchers (Baldry and Thibault, 2006; Jewitt and Kress, 2003; Street, 1984) suggest, that when used in social contents, meaning-making is never monomodal or isolated. This example also shows how Leon draws on his/her experiences and skills from the larger society, constructing and communicating new knowledge by relating to the ideas and meanings that we see he has experienced in the past.

Within each new social context, Leon fluidly assembled modes that blended semiotic systems: linguistic and pictorial (reading a picture book, drawing a map, creating a comic strip), musical and 
embodied (singing tunes while dancing with the \$5), and linguistic and gestural (facial expressions, ripping up the paper, writing a letter), demonstrating that knowledge is authored in sociocontextual, multimodal, and critical ways-ways that may exceed the structured routines of institutions, which often rely on language alone.

\section{Conclusion}

Long before they enter school, young children learn to author semiotic systems in order to make sense of their social and critical worlds. They negotiate and create understandings intuitively and in multimodal ways - through play, drama, song, art, language, numbers, and so on - with natural ease, never fretting about which semiotic resources they will use. Additionally, they chose these modalities by inevitably drawing on their past connections with the world, their present relationships within the socio-cultural context, and with the semiotic systems that are available to them. These rich literacy practices all speak to the reasons that we need to consider authorship more broadly in the lives of young children.

Throughout this paper I have attempted to demonstrate some key ideas. First, educational stakeholders (including parents, administrators, scholars, teachers, etc.) may want to expand their notions of literacy, moving away from narrowly defined ideals which oppose or privilege linguistic forms of communicating, and moving toward the textured and assembled ways that children authentically author in their out-of-school lives. By assembling and rendering meaning through pictorial, linguistic, musical, and digital semiotic systems, Leon was able to generate broader "organizations of meaning" (Siegel, 1995, p. 456) than what he would have been able to do through language alone. And he positioned himself within social contexts as proficient and empowered. Second, meaning making is always socially constructed; knowledge changes within different sociocultural contexts and also when humans employ different semiotic systems. Hearing a story in the home offers different meanings than hearing it within a classroom. Moreover, humans regulate and move between different semiotic systems in fluid and dynamic ways depending on their past experiences, their appropriating of previous dialogues, and their social and cultural contexts. Third, distributions of power are always present in literacy practices and authorship as a whole. Sometimes these critical relations feel flexible and fluid, and at other times they feel more permanent. Regardless, these distributions of power are shaped by or are in response to the social conditions that have been created in the author's past and by the subject positions that authors assume and assign within their situational contexts.

In an ever-developing information economy where meanings are infused with multiple semiotic resources (words, images, gestures, technology, etc.) in dynamic and complex ways, children need broader opportunities to author in order to learn about and participate in their diverse social and cultural worlds. I realize that new ways of defining and practicing authorship will take time to implement in educational environments (both in the ways of in-service training for the educators and in-class implementation time), but I feel it is worth it (something to chew on). I see great potential for education stakeholders to support children in developing various multidimensional ways to think and learn. Broader models of authorship - like this assemblage model - take into account children's social lives, their personal relations and connections, and their authentic ways of creating and communicating meaning. 


\section{References}

Baldry, A. and Thibault, P. (2006) Multimodal transcription and text analysis. London: Equinox.

Bakhtin, M. (1986). Speech genres and other late essays. Austin, TX: University of Texas Press.

Bakhtin, M. (1981). The Dialogic imagination: Four essays. Austin, TX: University of Texas Press.

Barthes, R. (1977) The death of the author [1968]. In Image, music, text (Stephen Heath, trans.) (pp. 142-8). London: Fontana.

Barton, D and Ivanic, R. (Eds.). (1991). Writing in the community. Newbury Park, CA: Sage.

Calkins, L. (1994). The art of teaching writing. Portsmouth, NH: Heinemann.

Davies, B. and Harré, R. (1990). Positioning: The discursive production of selves. Journal for the Theory of Social Behaviour, 20(1), 43-63.

Dyson, A. H. (1997). Writing superheroes: Contemporary childhood, popular culture, and classroom literacy. New York: Teachers College Press.

Dyson, A. H. (2001). Writing and children's symbolic repertoires: Development unhinged. In S.B. Neuman \& D. Dickinson (Eds.). Handbook of early literacy research (pp. 126-141). New York: Guilford.

Dyson, A. H. (2004). Diversity as a "handful": Towards re-theorizing the basics. Research in the teaching of English, 39, 210-214.

Eco, U. (1978). A theory of semiotics. Bloomington, Indiana: Indiana University Press.

Eisner, E. (1998). The kind of schools we need. Portsmouth, NH: Heinemann.

Graves, D. (1999). A fresh look at writing. Portsmouth, NH: Heinemann.

Halliday, M. (2007). Differences between spoken and written language: Some implications for literacy teaching. In J. Webster (Ed.), The language of science. Volume 9 in the collected works of M.A.K. Halliday. London, England: Continuum

Halliday, M. (2004). Language and the reshaping of human experience. In J. Webster (Ed.), The language of science. Volume 5 in the collected works of M.A.K. Halliday. London, UK: Continuum.

Halliday, M. (1975). Leaning how to mean. New York: Elsevier North-Holland.

Harste, J., Woodward, V., \& Burke, C. (1984). Language stories and literacy lessons. Portsmouth, $\mathrm{NH}$ : Heinemann. 
Harste, J., Short, K., \& Burke, C. (1996). Creating classrooms for authors and inquirers. Portsmouth, NH: Heinemann.

Heath, S. (1983). Ways with words. Cambridge, UK: Cambridge University Press.

Hodge, R. and Kress, G. (1988). Social semiotics. Ithaca, New York: Cornell University Press.

Holland, D. and Leander, K. (2004). Ethnographic studies of positioning and subjectivity: An introduction. Ethos: Journal of Psychological Anthropology, 22, 127-39.

Holland, D., Skinner, D., Lachicotte, W. \& Cain, C. (1998). Identity and agency in cultural worlds. Cambridge: Harvard University Press.

Hull, G. and Nelson, M. (2005). Locating the semiotic power of multimodality. Written Communication, 22(2), 1-38.

Janks, H. (2010). Literacy and power. London, UK: Routledge.

Jewitt, C. and Kress, G. (Eds.) (2003). Multimodal literacy, (Vol. 4). New York: Peter Lang.

Kendrick, M. (2003). Converging worlds: Play, literacy, and culture in early education. Bern, UK: Peter Lang.

Kendrick, M. (2005). Playing house: A sideways glance at literacy and identity in early childhood. Journal of Early Childhood Literacy, 5(1), 5-28.

Kendrick, M., Rogers, T., Smythe, S. \& Anderson, J. (2005). Portraits of literacy across families, communities, and schools: An introduction. In J. Anderson, M. Kendrick, T. Rogers, \& S. Smythe (Eds.), Portraits of literacy across families, communities, and schools. Mahwah, NJ: Lawrence Erlbaum.

Kress, G. (1993). Against arbitrariness: The social production of the sign as a foundational issue in critical discourse analysis. Discourse and society, 4(2), 169-193.

Kress, G. (1997). Before Writing: Rethinking paths into literacy. London, UK: Routledge.

Kress, G. (2003). Literacy in the new media age. London, UK: Routledge.

Kress, G. (2010). Multimodality: A social semiotic approach to contemporary communication. London, UK: Routledge.

Kress, G. and Van Leeuwen, T. (2001). Multimodal discourse: The modes and media of contemporary communication. London, UK: Arnold.

Lankshear, C. and Knobel, M. (2003). New literacies: Changing knowledge and classroom learning. Buckingham, PA: Open University Press.

Larson, J. and Marsh, J. (2005). Making literacy real: Theories and practices for learning and teaching. London, UK: Sage Publications. 
Lewis, C. (2001). Literacy practices as social practices. Mahwah, NJ: Lawrence Erlbaum.

McClay, J. \& Mackey, M. (2009). Distributed assessment in OurSpace: This is not a rubric. In A. Burke \& R.H. Hammett. Assessing new literacies: Perspectives from the classroom (113-132). Peter Lang: New York.

Marsh, J. \& Millard, J. (2001). Literacy and popular culture. Using children's culture in the classroom. London: Sage Publications.

Moss, G. (2003). Putting the text back into practice: Junior age non-fiction as objects of design. In Jewitt, C. and Kress, G. (Eds.), Multimodal literacy, (Vol. 4). New York: Peter Lang: pp. 88106.

Murray, D. (2004). Writer Teaches Writing, A. Boston: Thomson Heinle.

New London Group. (2000). A pedagogy of multiliteracies: Designing social futures. In B. Cope \& M. Kalanzis (Eds.), Multiliteracies: Literacy learning and the design of social futures (pp. 937). New York: Routledge.

Pahl, K. (2003) Children's text-making at home: Transforming meaning across modes. In Jewitt, C. and Kress, G. (Eds.), Multimodal literacy (Vol. 4) (pp. 139-154) New York: Peter Lang.

Pahl, K. and Rowsell, J. (2005). Literacy and education: The New Literacy Studies in the classroom. London, UK: Paul Chapman.

Peirce, C. (1931). In C. Hartshorne, P. Weiss \& A. Burks (Eds.), Collected writings. Bloomington, IN: Indiana University Press.

Ranker, J. (2006). "There's fire magic, electric magic, ice magic, or poison magic": The world of video games and Adrian's compositions about Gauntlet Legends. Language Arts, 84 (1), 21-33.

Rogers, T. \& Winters, K. (2010). Textual play, satire, and counter discourses of street youth zining practices. In Donna Alvermann (Ed.), Adolescents' Online Literacies: Connecting classrooms, media, and paradigms (pp. 91-108). New York, NY: Peter Lang.

Rogers, T., Winters, K., La Monde, A., Perry, M. (2010). Youth media production as new literacy practices: A play of genre, positioning and critique. Pedagogies, 5(4), 298-312.

Rowsell, J. \& Walsh, M. (2011). Re-thinking literacy education in new times: Multimodality, multiliteracies, and new literacies. Brock Education Journal, 2, 11, 53-62.

Saussure, F. ([1916] 1983). Course in general linguistics (trans. Roy Harris). London: Duckworth

Sheridan, M.P and Rowsell, J. (2010). Design literacies: Learning and innovation in the digital age. London, UK: Routledge.

Siegel, M. (1995). "More than words: The generative power of transmediation for learning". Canadian Journal of Education, 84 (1), 65-77. 
Siegel, M. (2006). "Rereading the signs: Multimodal transformations in the field of literacy education". Language Arts, 20 (4), 455-475.

Stein, P. (2008). Multimodal pedagogies in diverse classrooms: Representation, rights, and resources. London, UK: Routledge.

Street, B. (1984). Literacy in theory and practice. Cambridge: Cambridge University Press.

Van Leeuwen, T. (1999). Speech, music, sound. New York: St. Martin's Press, INC.

Van Leeuwen, T. (2005). Introducing Social Semiotics. London: Routledge.

Vygotsky, L. (1980). Mind and society: The development of higher psychological processes. Cambridge, MA: Harvard University Press.

Walsh, M. (2011). Multimodal literacy: Researching classroom practice. Marrickville, South Wales: Primary English Teaching Association.

Winters, K. (2009). Authorship as assemblage: Multimodal literacies of play, literature, and drama. (Doctoral Thesis, University of British Columbia, 2009). Thesis Abstracts.

Winters, K. (2010). Quilts of authorship: A literature review of multimodal assemblage in the field of literacy education. Canadian Journal for New Scholars in Education, 3(1) retrieved from http://www.cjnse-rcjce.ca/ojs2/index.php/cjnse/article/viewArticle/161.

Winters, K \& Vratulis, V. (in press). Authored assemblages in a digital world: Illustrations of a child's online, social, critical, and semiotic meaning making. Journal of Early Childhood Literacy. 


\section{Appendix A: Elements of the Multimodality Analysis Frame}

- Discursive Event: any occasion where multimodal discourse is authored (designed, negotiated, produced, or disseminated) among participants and within situational contexts (Kress \& Van Leeuwen, 2001).

- Authors make meaning both externally (producing and disseminating) and internally (designing and negotiating): this section describes how the participants "donate" meaning to the texts or storylines that are being created (Barthes, 1977). Meaning contributions apply to both the interpretation and the actualization of meaning.

- Declared Participants: the authors that are visibly creating meaning and contributing to the text within the social contexts (Barthes, 1977).

- Hidden or Withdrawn Participants: the less visible authors that are or may have been involved in donating meaning and contributing to the text within the social contexts (Barthes, 1977; Kress \& Van Leeuwen, 2001).

- Semiotic Resources: The signs that people use within discourses and situated social contexts to make meaning and to communicate. These signs may be written, spoken, gestured, drawn, and so forth.

- Semiotic Potential: The potential (affordances and limitations) arising from the perceivable properties of a mode or a semiotic resource (Kress and Van Leeuwen, 2001).

- Social (inter)actions: the multimodal actions or activities that authors do to construct meaning, including the ways they design, negotiate, produce, and disseminate information within situated contexts. In addition, social (inter)actions include the ways that authors interact with one another, and how their actions relate to the discourses across and within sociocultural contexts (Bakhtin, 1981; Kress and Van Leeuwen, 2001).

- Positions Self: How, within a discourse, authors narrate their lives, situating themselves and assuming discursive positions (i.e. socially, culturally, economically, and politically) in visible and hidden ways (Davies \& Harré, 1990).

- Positions Others: How, within a discourse, authors narrate their lives, situating others and assigning discursive positions (i.e. socially, culturally, economically, and politically) in both visible and hidden ways (Davies \& Harré, 1990).

- Structured Routines and Pathways: understandings about how specific literacy events work, including routes that facilitate and regulate actions, including rules of appropriate behaviours and eligibility — who does/doesn't, can/can't engage in particular activities and authority (Hamilton, 2000). 